\title{
Transport of Indole 3-acetic Acid through Bulk Liquid Membrane Influence of Carrier in the Diffusion Process
}

\author{
IOANA DIACONU1*, ECATERINA ANCA SERBAN², GEORGIANA ILEANA BADEA ${ }^{3 *}$, ELENA RUSE ${ }^{1 *}$ \\ 'University Politehnica of Bucharest, Faculty of Applied Chemistry and Material Science, Department Analytical Chemistry and \\ Environmental Engineering, 1-7 Polizu Str., 011061, Bucharest, Romania \\ ${ }^{2}$ National Research and Development Institute for Industrial Ecology-ECOIND, 71-73 Drumul Podul Dambovitei Str., 060652 , \\ Bucharest, Romania \\ ${ }^{3}$ National Institute for Biological Sciences, Centre of Bioanalysis, 296 Spl. Independentei, 060031, Bucharest, Romania
}

\begin{abstract}
The paper presents a study of the phenomena that take place at membrane system interfaces in the process of indole-3-acetic acid (IAA) transport. The results were obtained in a bulk liquid membrane system using trioctylamine, tributylphosphate, trioctilphosphine oxide as carriers in chloroform. The main equilibriums that take place at the interface feed phase $\%$ membrane phase were identified and the diffusion coefficient of the indole-3-acetic acid complex (DLS) and the extraction constant (Kex) were assessed. The influence of the chemical potential gradient on these parameters was considered.
\end{abstract}

Keywords: bulk liquid membranes, indole-3-acetic acid, TOA, TOPO, TBP

Phytohormones are substances with a very important role in plant regulatory processes such as cell division, growth and reproduction of the plant [1,2]. The main classes of phytohormones are: abscisic acid, salicylic acid, cytokinins, ethylene, giberilines and auxins [3]. The Auxines were discovered at the end of the 19th century and were named so after the greek word auxein that means to grow or to increase [4]. A representative phytohormone of the auxin class is indole 3-acetic acid (IAA). IAA is found into various plant development stages, being a natural plant phytohormon produced by the root, sprouts or apicultural meristems. IAA can influence both positively and negatively the growth and development of the plant in cell division, elongation or differentiation processes. IAA can be produced by both plants and soil bacteria such as: Azospirillum brasilense, Pseudomonas syringae, Agrobacterium tumefaciens, Bradyrhizobium japonicum sau Acinetobacter baumannii. [5-7]. The treatment of plants with IAA in combination with EDTA may have adverse effects on health due to the accumulation of $\mathrm{Pb}$ in leaves, for example in the treatment of alfalfa [8]. These negative effects can be reduced by treating the plants with a mixture of IAA and salicylic acid. The presence of IAA and salicylic acid inhibited the transport of cadmium from the root to the shoots of young saplings by modifying the antioxidant defensive system, thus preventing cadmium damage [9]. IAA is a compound with moderate toxicity according to the European Chemicals Agency (ECHA), irritating to the eye and skin. The toxic effects of IAA can be seen on internal organs such as liver or kidney when accidental inhalation or absorption through the skin occurs [10].

A number of methods have been developed for IAA detection such as high performance liquid chromatography, gas chromatography, electrochemical detection or capillary electrophoresis [1].

IAA is found in plants at very low concentrations at ng / $g[1,3]$, which is why a preliminary separation should be made to better identify it in order to determine the exact level of this plantregulator. Organic acids can be separated by multiple methods such as liquid-liquid extraction, adsorption, precipitation, osmosis, ion exchange, ultrafiltration, nanofiltration or membrane separation [1121].
A special attention is paid to liquid membranes. Liquid membranes are intensively used due to their many advantages such as: selectivity, simplicity in operation, low cost of process, high energy efficiency, easy to scale up [22-26].

An important feature of the liquid membranes is that the extraction step and the stripping step take place in the same system at the same time.

Liquid membranes can be used in many fields to achieve the recovery of useful products such as: metallurgy, pharmaceutical industry or environmental protection.

The range of compounds that can be separated or recovered by the liquid membrane technique can include compounds such as: acids, amines, phenolic compounds, amino acids or even drugs [27-30].

The selectivity of the process through liquid membranes can be substantially improved by using carriers. Among the commonly used carriers are: di- (2-ethylhexyl) phosphoric acid (D2EHPA), N - Methyl-N, N, N trioctylammonium chloride (Aliquat 336), tributyl phosphate (TBP) , 4-trimethylpentyl) phosphinic acid (Cyanex 272), trioctylphosphine oxide (TOPO), tri-noctylamine (TOA) (Alamine 300). In this paper, a study was conducted on the diffusion transport of indole-3-acetic acid through a bulk liquid membrane system. Processspecific parameters were evaluated for the use of three commercial transporters.

\section{Experimental part}

Materials and method

For the experimental study of the transport of indole-3acetic acid through bulk liquid membranes, analytical grade reagents were used. Indole-3-acetic acid was purchased from Merck and the chloroform used for membrane preparation was purchased from Sigma-Aldrich. As carriers were used tributylphosphate (TBP) and Trioctylphosphine oxide (TOPO) purchased from Sigma-Aldrich and the trioctylamine purchased from Flucka. As the stripping agent sodium hydroxide was used and it was also purchased from Merck.

The transport experiments were carried out in a tube in tube type experimental device preented in a previous paper [29]. The membrane system consisted of:

* email: diaconuioana12@yahoo.com; truicageorgiana@yahoo.com; e_ruse@chim.upb.ro 
- Feed phase solution of indole-3-acetic acid in the concentration range $10^{-4}-10^{-3} \mathrm{~mol} / \mathrm{L}$

- Membrane phase - carrier solution: trioctylamine (TOA), Trioctylphosphine oxide (TOPO), tributyl phosphate (TBP) $10^{-2} \mathrm{~mol} / \mathrm{L}$ in chloroform.

- Stripping phase - $\mathrm{NaOH}$ solution in the concentration range $10^{-2}-10^{-1} \mathrm{~mol} / \mathrm{L}$.

The indole-3-acetic acid content was determined by molecular absorption spectrometry in the ultraviolet domain. Indole-3-acetic acid has a maximum absorption band at $\lambda=280 \mathrm{~nm}$. For this purpose a LAMBDA 750 spectrophotometer (Perkin Elmer Co.) was used.

\section{Results and discussions}

In agitated bulk liquid membrane systems the transport of the solute from a feed phase (donor) to a stripping phase (receiving) takes place through convective convection and diffusion processes as can be seen from the representation of figure 1.

At the interfaces of the membrane system a series of distribution equilibriums of the solute and of the solutecarrier complex takes place as follows:

$$
\begin{aligned}
& (I A A)_{F S} \rightleftharpoons(I A A)_{m} \\
& (I A A)_{F S}+(L)_{F S}(L-I A A)_{F S} \\
& (I A A)_{m}+(L)_{m}(L-I A A)_{m} \\
& (L-I A A)_{F S}(L-I A A)_{m}
\end{aligned}
$$

where

IAA = indole-3-acetic acid

$\mathrm{L}=$ ligand (carrier)

$L-I A A=$ complex formed by the ligand with indole-3acetic acid

Similar equilibrium also occur at the membrane\% stripping phase interface

Based on these equilibriums we define a series of constants such as:

-the association constant that characterizes the formation of the complex substrate-ligand in the membrane phase, Kas,

$$
K_{a s}=\frac{[L-L A A]_{m}}{[L A A]_{m}[L]_{m}}
$$

-the association constant that characterizes the formation of the indole-3-acetic acid- ligand complex in the source phase, Kw,

$$
K_{w}=\frac{[L-L A A]_{w}}{L A A_{w}[L]_{w}}
$$

-the repartition constant of the ligand between the two phases of membrane system: source-membrane phase, $\mathrm{RL}$,

$$
R_{L}=\frac{[L]_{m}}{[L]_{w}}
$$

-the reparation constant of the indole-3-ace4tic acid between the two phases of the system, feed phase and membrane, RIAA

$$
R_{L A A}=\frac{[L A A]_{m}}{[L A A]_{w}}
$$

-the extraction constant of ligand substrate complex is given by the relationship:

$$
K_{e x}=\frac{[L-L A A]_{m}}{[L A A]_{w}[L]_{m}}
$$

By the correlation of these constants the fallowing relationship results:

$$
K_{e x}=K_{a s} \times R_{L A A}
$$

Namely the organic substrate extraction constant is equal to the product of the association constant that characterizes the formation of the ligand-organic substrate complex and the distribution constant of the same organic substrate at the interface feed phase / organic substrate.

At interfaces of the membrane system, transport takes place exclusively through diffusion processes governed by Fick's law:

$$
J=D \frac{d C}{d x}
$$

The total flux $\left(\mathrm{J}_{\text {tot }}\right.$ ) of indole-3-acetic acid transported to the membrane system interfaces can be considered as the sum of two fluxes - the flux in the absence of the transport ligand $\left(\mathrm{J}_{0}\right)$ and the presence of the carrier $\left(\mathrm{J}_{\mathrm{as}}\right)$ :

$$
\mathrm{J}_{\mathrm{tot}}=\mathrm{J}_{0}+\mathrm{J}_{\mathrm{as}}
$$

Applying Fick's law we get:

$$
J_{\text {tot }}=D_{L A A} \frac{d[L A A]_{m}}{d x}+D_{L-L A A} \frac{d[L-L A A]_{m}}{d x}
$$

where:

DIAA = diffusion coefficient of indole-3-acetic acid

$\mathrm{d}[\mathrm{IAA}] \mathrm{m}=$ variation of the concentration of indole-3acetic acid in the membrane at the interface with the feed phase

$d[L-I A A] m=$ variation of complex concentration in the membrane at the interface with the feed phase

$D L-I A A=$ diffusion coefficient of the indole-3-acetic acidcarrier ligand complex.

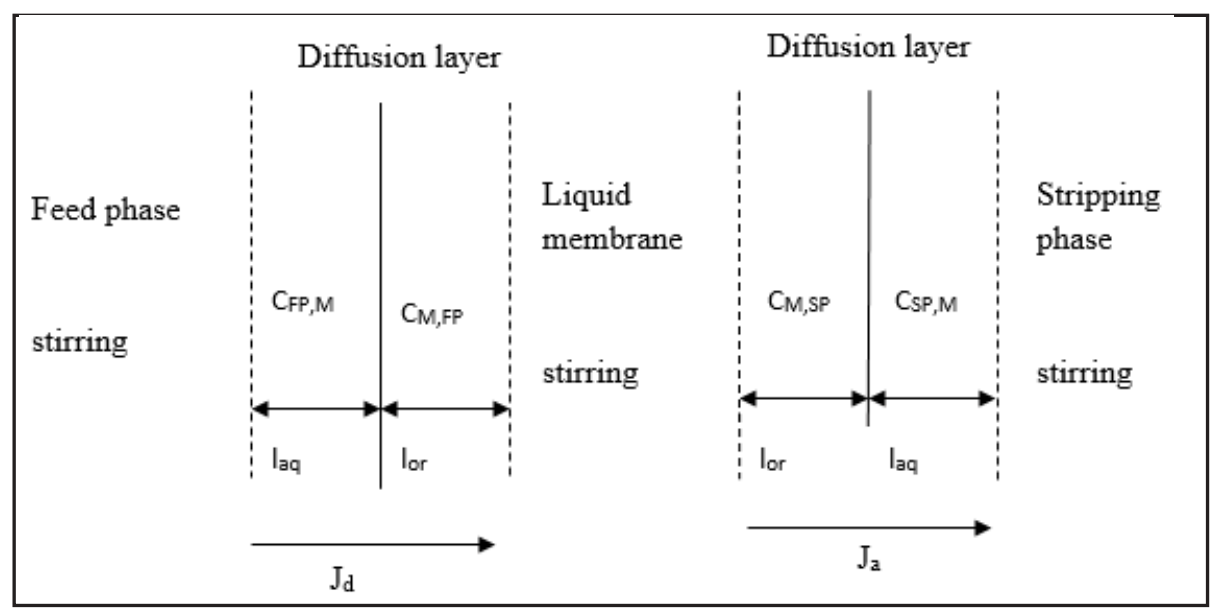

Fig.1 Schematic representation of the pertraction in an agitated bulk liquid membrane system 
Making the carriers balance on the phases of the membrane system, we obtain:

$$
[\mathrm{L}]_{\mathrm{tot}}=\left([\mathrm{L}]_{\mathrm{m}}+[\mathrm{L}-\mathrm{IAA}]_{\mathrm{m}}\right)+1 / \operatorname{Prs}\left([\mathrm{L}]_{\mathrm{FS}}+[\mathrm{L}-\mathrm{IAA}] \mathrm{FS}\right)+
$$

$$
+1 / \text { PrR }_{L}[\mathrm{~L}] \mathrm{FR}
$$

where:

$\mathrm{P}_{\mathrm{FS}}=\mathrm{V}_{\mathrm{FS}} / \mathrm{V}_{\mathrm{m}}$

$\mathrm{P}_{\mathrm{FB}}=\mathrm{V}_{\mathrm{FR}} / \mathrm{V}_{\mathrm{m}}$

$V F S=$ feed phase volume

$\mathrm{Vm}=$ the volume of the membrane

VFR $=$ stripp phase volume

Introducing in this relation the sizes that characterize the balances from the interface feed phase / membrane it is obtained:

$$
\begin{gathered}
{[L]=\frac{[L-L A A]_{m}}{K_{e x}[L A A]_{F S}^{0}}\left(1+\frac{1}{P_{F S} R_{L}}+\frac{1}{P_{F R} R_{L}}+\frac{K_{w}[L A A]}{P_{L A A}}\right)+} \\
+[L-L A A]_{m}
\end{gathered}
$$

From which follows:

$$
\frac{[L]_{m}^{0}}{J_{a s} \cdot d}=\frac{1}{D_{L-L A A}}+H \frac{1}{K_{e x}[L A A]_{F S}^{0} D_{L-L A A}}
$$

$\mathrm{H}$ is a constant with values close to the unit

$$
1+\frac{1}{P_{F S} R_{L}}+\frac{1}{P_{F R} R_{L}}+\frac{K_{w}[\operatorname{LAA}]}{P_{s}}=H
$$

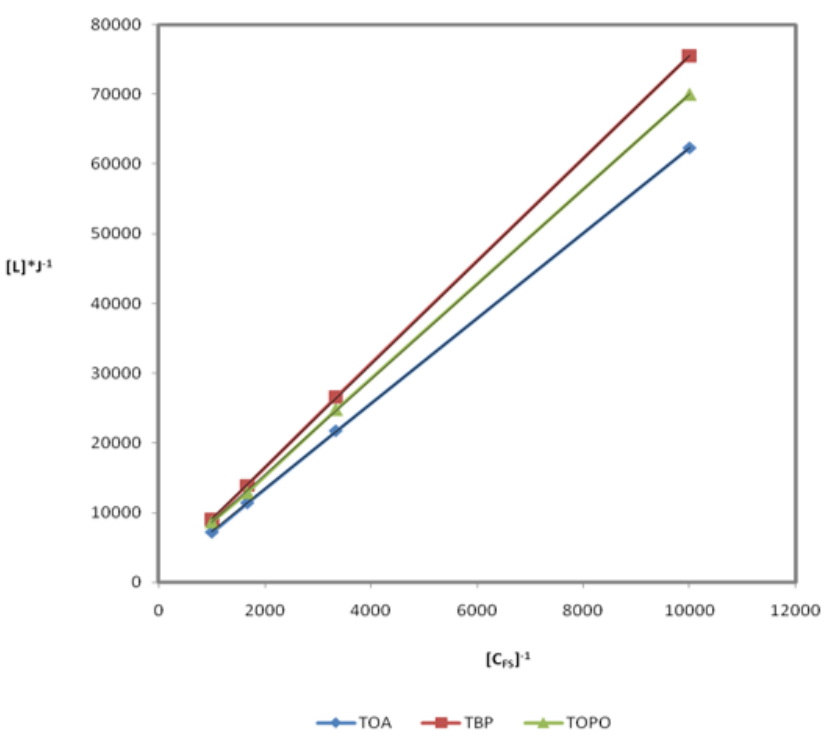

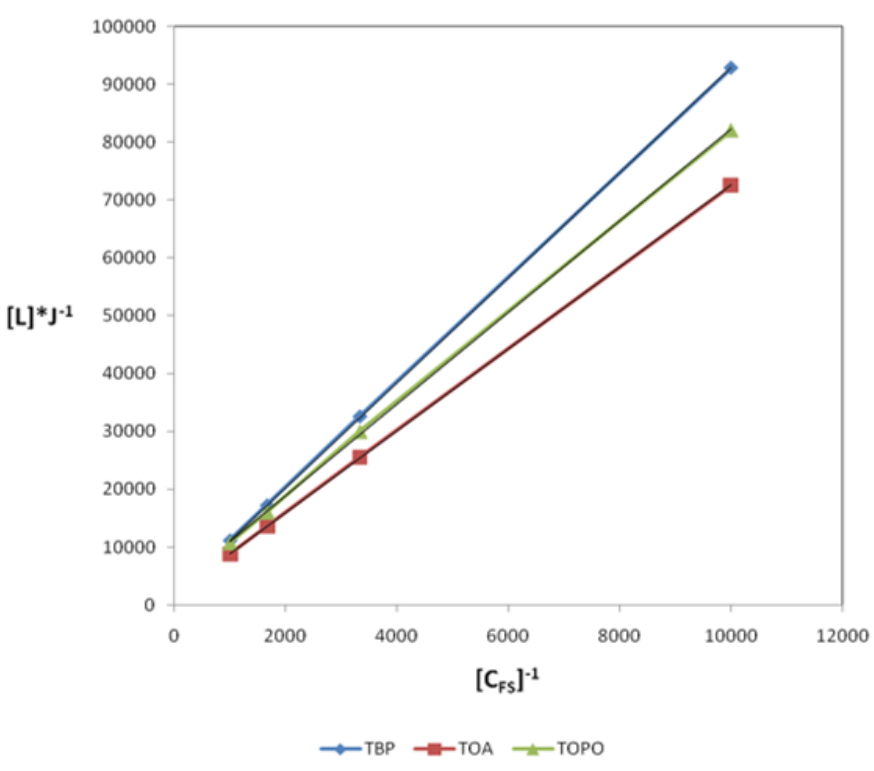

Fig. 3. Variation of $[L] x]^{-1}$ as a function of $[I A A]-1$ on the transport of indole-3-acetic acid

Working conditions: The feed phase solution of indole-3-acetic acid in the concentration range $10^{-4}-10^{-3} \mathrm{~mol} / \mathrm{L}$; membrane-carrier solution: TOA, TOPO, TBP concentration $10^{-2} \mathrm{~mol} / \mathrm{L}$ in chloroform, stripp phase: $\mathrm{NaOH} 10^{-2} \mathrm{~mol} / \mathrm{L}$ solution. Transport time $4 \mathrm{~h}$

The relationship allows the assesment of the DL-IAA diffusion coeficient and the Kex extraction constant based on the linear correlation between the product $[L].]^{-1}$ as a function of $[I A A]^{-1}$. Thus, the diffusion coefficient of the complex can be calculated from the intercept value, and $\mathrm{K}$ from the slope.

Based on the results obtained for the transport of indole3 -acetic acid in figures 2 and 3 , the linear correlation between the product [L] . $]^{-1}$ as a function of [IAA] ${ }^{-1}$ at two concentration values of the stripping agent, $\mathrm{NaOH} 1 \mathrm{~mol} / \mathrm{L}$ and $10^{-2} \mathrm{~mol} / \mathrm{L}$.

Fig 2. Variation of $[\mathrm{L}] \mathrm{X}]^{-1}$ as a function of $[\mid \mathrm{IAA}]^{-1}$ at the transport of indole 3-acetic acid

Working conditions: The feed phase: solution of indole-3-acetic acid in the concentration range $10^{-4}-10^{-3} \mathrm{~mol} / \mathrm{L}$; membrane-carrier solution: TOA, TOPO, TBP $10^{-2} \mathrm{~mol} / \mathrm{L}$ in chloroform, strip phase: 1 $\mathrm{mol} / \mathrm{L} \mathrm{NaOH}$ solution. Transport time: $4 \mathrm{~h}$

\begin{tabular}{|l|l|l|l|}
\hline $\begin{array}{l}\text { Concentration of } \\
\text { stripping agent } \\
(\mathrm{NaOH}), \mathrm{mol} / \mathrm{L}\end{array}$ & Carrier & $\mathrm{D}_{\mathrm{L}-\mathrm{LA} \cdot \mathrm{A} X 10^{4} / \mathrm{mol}_{\mathrm{cm}} \mathrm{L}^{-1}}$ & $\mathrm{~K}_{\text {ex }}$ \\
\hline \multirow{4}{*}{$1 \mathrm{~mol} / \mathrm{L}$} & TOA & 8.46 & \\
\cline { 2 - 4 } & TBP & 5.91 & 193.163 \\
\cline { 2 - 4 } & TOPO & 5.39 & 228.563 \\
\hline \multirow{3}{*}{$10^{-2} \mathrm{~mol} / \mathrm{L}$} & TOA & 5.87 & 272.007 \\
\cline { 2 - 4 } & TBP & 4.75 & 239.577 \\
\cline { 2 - 4 } & TOPO & 3.33 & 231.260 \\
\hline
\end{tabular}

Table 1

TRANSPORT PARAMETERS

CALCULATED ACCORDING TO EQUATION 18 
From the experimental data obtained it is found that both the diffusion coefficients of the organic substratecarrier complexes and their extraction constants are of the same order of magnitude. Analyzing these results in correlation with the chemical potential gradient one observes a relation of proportionality with diffusion coefficients. They have higher values when using a stripping phase with a higher concentration of the stripping agent. The diffusion coefficients depending on the carrier vary as follows: $D_{\text {TOA-AA }}>D_{\text {TRP-IAA }}>D_{\text {TOPO-AAA }}$ regardless the concentration of the stripping agent. Regarding transport efficiency of the carrier we have the sequence: TOA> TOPO > TBP regardless the concentration of the stripping agent in the stripping phase. This influence of the carrier on the efficiency of the process can be correlated with the nature of the carrier-organic substrate interactions. In the case of TOA, we have donor-acceptor interactions while in the other two carriers we have weaker interactions involving phosphoryl groups.

\section{Conclusions}

The main objective of this paper was to determine some parameters such as the diffusion coefficient of the carrierorganic substrate complex and its extraction constant in the case of transport of indole-3-acetic acid through bulk liquid membranes in the presence of TOA, TOPO, TBP. Calculations were made based on a mathematical model that establishes a linear correlation between the product $\left.[\mathrm{L}]^{.}\right]^{-1}$ as by $[\mathrm{IAA}]^{-1}$. It has been found that for the three carriers are obtained values of these parameters of the same order of magnitude. The diffusion coefficient values are proportional to the chemical potential gradient. The role of the carrier has been determined taking into account the nature of its interactions with the transported substrate. Thus, the best transport yields are obtained with the ligand TOA. In this case also the highest values of diffusion coefficients are obtained.

\section{References}

1.ZHOU, Y., XU, Z., WANG, M., MENG, X., YIN, H. Electrochim. Acta, 96, 2013, p. 66

2.SANTNER, A., CALDERON-VILLALOBOS, L. I. A., ESTELLE, M., Nat. Chem. Biol., vol. 5, no.5, 2009, p. 301

3.CAMPANELLA, B., PULIDORI, E., ONOR, M., PASSAGLIA, E., TEGLI, S., IZQUIERDO, C. G., BRAMANTI, Microchem. J., vol 128, 2016, p. 68 4.TROMAS, A., \& PERROT-RECHENMANN, C, C. R., Biologies vol. 333, no 4, 2010, p. 297

5.ZHAO, Y., Annual Rev Plant Biol., vol 61, 2010, p. 49
6.DONATI, A. J., LEE, H. I., LEVEAU, J. H., CHANG, W. S., PloS one, vol 8, No.10, 2013, e76559, doi:10.1371/journal.pone.0076559

7.LIN, H. R., SHU, H. Y., LIN, G. H. , Microbiol. Res, vol. 216, 2018, p. 30

8.LOPEZ, M. L., PERALTA-VIDEA, J. R., BENITEZ, T., GARDEATORRESDEY, J. L., Chemosphere, vol. 61, no. 4, 2005, p.595

9.AGAMI, R. A., MOHAMED, G. F., Ecotox. Environ. Safety, 94, 2013, p.164

10.LIU, F., TANG, J., XU, J., SHU, Y., XU, Q., WANG, H., HU, X., Biosens Bioelectron., vol. 86, 2016, p. 871

11.SERBAN, E. A., DIACONU, I., MIREA, C. M., RUSE, E., NECHIFOR, G., Rev.Chim.(Bucharest), 67, no.4, 2016, p.634

12.KUMAR, S., KAMSONLIAN, S., CHOMAL, N., Int J Chem Eng Appl, vol. 5, no. 6, 2014, p.506.

13.GIASUDDIN, A. B., KANEL, S. R., CHOI, H., Environ. Sci. Technol., vol 41, no. 6, 2007, p. 2022

14. MANNING, K. Anal.Biochem., vol. 195, no.1, 1991, p.45

15.TEELLA, A., HUBER, G. W., FORD, D. M., J. Membr. Sci., vol 378, no. 1-2, 2011, p. 495

16.NAGARALE, R. K., GOHIL, G. S., \& SHAHI, V. K. , Adv.Colloid Interface Sci., vol 119 no. 2-3, 2006, p. 97-130

17.ALGAMDI, M. S., ALSOHAIMI, I. H., LAWLER, J., ALI, H. M., ALDAWSARI, A. M., HASSAN, H. M., Sep.Purif. Technol.223, 2019, p.17 18.CASCAVAL, D., GALACTION, A. I., ONISCU, C., Hemijska industrija, vol 58 no 3, 2004, p.97-

19.KAUR, A., VOHRA, D. K. Indian J .Chem Technol, vol 17,.2010, p 133 20.YANG, L., CHEN, X. Q., JIAO, F. P. J, Braz.Chem. Soc., vol 20, no 8, 2009, p. 1493-1498

21. BAYLAN, N., CEHRELI, S., OZPARLAK, N. J., Dispers. Sci.Technol.,vol 38 no. 6, 2017, p. 895

22. SERBAN, E. A., DIACONU, I., RUSE, E., BADEA, G. E., CUCIUREANU, A., NECHIFOR, G. Rev. Chim.(Bucharest), 68, no. 5, 2017, p. 903 23.SERBAN, E. A., DIACONU, I., RUSE, E., EFTIMIETOTU, E., NECHIFOR, G., Rev. Roum. Chim., 62 no. 6-7, 2017, p. 505

24.ZAHARIA, I., ABOUL-ENEIN, H. Y., DIACONU, I., RUSE, E., BUNACIU, A. A., NECHIFOR, G., J Iran Chem Soc, vol 10, no. 6, 2013, p. 1129 25.SZCZEPANSKI, P. Chem.Eng. Sci., 185, 2018, p. 141

26.GRANADO-CASTRO, M. D., DIAZ-DE-ALBA, M., CHINCHILLA-REAL, I., GALINDO-RIANO, M. D., GARCIA-VARGAS, M., CASANUEVAMARENCO, M. J. Talanta, 192, 2019, p. 374

27.J OSCEANU, A. M., RUSE, E., LUCA, C., CERBU, E. Mat. Sci. Eng. C, vol 18, no.1-2, 2001, p. 79-85

28. KIM, L., HAMDI, A., STANCU, A. D., SOUANE, R., MUTIHAC, L., VICENS, J. J. Incl. Phenom.. Macrocycl.. Chem, vol 66, no 1-2, 2010,p.55 29.DIACONU, I., ABOUL-ENEIN, H. Y., AL-OMAR, M. A., NECHIFOR, G., RUSE, E., BUNACIU, A. A., TOTU, E. E., Arab. J. Chem., 4(1), 2011, p. 99-103.

30.ALIZADEH, T., MEMARBASHI, N., Sep. Purif. Technol., 90, 2012, p.83

Manuscript received: $\mathbf{1 5 . 0 9 . 2 0 1 8}$ 